\title{
An Analysis of Controllability of Chinese Enterprises' Energy Investment Risk in Pakistan
}

\author{
Di Zhou \\ Macau university of science and technology \\ Macau 999078, China
}

\begin{abstract}
Recently, a news about china blocking three roads along the China-Pakistan economic corridor has aroused discussion and suspicion in Pakistan and the western media. They invariably discuss that why China withdraws investment in Pakistan's three road infrastructure project. But China has not yet to give specific reply. There is no doubt that China will fulfill all its contractual obligations to Pakistan. In particularly, this is reflected in Chinese enterprises' massive energy investment in Pakistan. However, Chinese enterprises' investment in Pakistan is not smooth, they will encounter risk, and China's withdrawal path may also have these worries. Therefore, the author takes an example of representative controllability of energy investment risk as the subject of this paper, takes the present situation of Chinese enterprises in Pakistani energy investment as object, points out that Chinese enterprises' energy investment projects in Pakistan are suffering or will confront with risks in politic, economy, culture, management system and other aspects and puts forward the relevant measures to control risks. It is very important to make China's enterprises continue to invest Pakistan with confidence. In a word, this can fulfill the Chinese enterprises' international responsibility on the "Belt and Road" Initiative.
\end{abstract}

Keywords-Chinese Enterprises; Pakistan; Energy Investment; Risk Controllability

\section{INTRODUCTION}

Hans J. Morgenthau said: "Who can join their other sources of oil and raw materials, who will greatly increase their own resources, and in the same proportion deprived of the opponent's resources."[1]. Robert Gilpin also believes that the United States should establish the sphere of influence of energy resources, open the market to friendly countries, or not exclude the participation of friendly countries.[2]. It can be said that the possession of energy resources such as petroleum is a judgment of the strength of the state and the strength of power. In recent years, with the enhancement of China's comprehensive national strength and the improvement of corporate economic strength, China's investincrease. Regardless of the importance attached to China's flagship brand's China-Pakistan Economic Corridor in China's "One Belt And Road" strategy, or from China's consideration of the value of China-Pakistan Free Trade Zone, energy investment in Pakistan has become a key project for Chinese companies to invest in Pakistan. . In 2015, Chinese President Xi Jinping signed with Pakistan the largest single investment contract in the history of China, worth 46 billion US dollars, of which energy is the main investment project.
Although China has a promising investment prospect in Pakistan, the frequent attacks in Pakistan, the hijacking of Chinese staff in Pakistan, the planning of events against the Chinese Embassy in Pakistan, and certain factors in the country have cast a shadow over Chinese investment in Pakistan. According to the "2017 "One Belt And Road" Energy Risk Investment Political Risk Assessment Report", there are 14 countries with higher risks of China's foreign energy resource investment, and Pakistan is among them. In this context, the risks involved in energy investment of Chinese companies in Pakistan are listed as research objects, and their multi-faceted causes are analyzed, and the countermeasures for controlling risks are of practical significance.

\section{OVERVIEW OF CHINESE COMPANIES' ENERGY INVESTMENT IN PAKISTAN}

\section{A. The meaning and characteristics of energy investment}

First, energy investment is a combination of two concepts of energy and investment. Refers to all energy-related aspects of the energy sector, including upstream energy exploration, development, midway transportation, and downstream energy refining and sales, in order to obtain material resources or profits that can provide some form of energy to human beings. Linkages, even energy flows in the energy industry infrastructure and energy services, and economic activities of operations [3]. In short, energy investment is the specific behavior of the owner of the asset to achieve its expected benefits, the capital operation in energy-related aspects and the corresponding economic activities that form energy assets. Second, the characteristics of energy investment energy investment has a large amount of capital and a high capital intensity. The construction period of energy investment is longer and the effect is slower. Thirdly, there are more uncertainties in energy investment, and companies will be accompanied by high risk rates while achieving high returns. energy investment is also related to the development speed of the national economy, the deployment effect of the national strategy, and the well-being of the people's livelihood.

\section{B. Definition and characteristics of investment risk}

Investment risk refers to the low return on investment caused by uncertain factors existing in specific spaces in all corners of the economy and society. At the same time, investment risks can be divided into internal investment risks and foreign investment risks. Therefore, whether it is internal 
investment or external investment risk has objective existence, non-determinism, harmfulness and relativity.

\section{The connotation and characteristics of energy investment risk}

In summary, the energy investment risk essentially refers to the degree of damage caused by the energy project, the strategic deployment of the country, and the welfare of the society in the process of energy project investment construction and operation. In other words, it also means that the actual effect of the investment entity on energy investment may deviate from the expected target of its investment, thus causing the decline and loss of the rate of return.

\section{Recent developments in energy investment of Chinese companies in Pakistan}

China's investment in Pakistan is mainly based on enterprises, and personal investment is minimal. "China Investment" in the following data and views is "investment of Chinese companies" in terms of its industry nature. According to information from Pakistan's "Business Record", Pakistan attracted foreign direct investment of 1.602 billion US dollars in the first nine months of 2017 , an increase of $12.4 \%$ over the same period last year of 1.425 billion US dollars. Among them, the investment from China totaled 595 million US dollars, ranking first. In March 2017, Pakistan's foreign direct investment reached US\$297 million, a year-on-year increase of $39 \%$. Among them, China's investment is 263 million US dollars.[4]. (See table 1).
TABLE I

CHINA'S SHARE OF FOREIGN DIRECT INVESTMENT IN PAKISTAN

\begin{tabular}{|c|c|c|c|}
\hline Time & $\begin{array}{l}\text { Foreign } \\
\text { investment } \\
\text { (Billion) }\end{array}$ & $\begin{array}{l}\text { Chinese } \\
\text { investment } \\
(\text { Billion })\end{array}$ & \multicolumn{2}{|l}{$\begin{array}{l}\text { Year-on-year } \\
\text { growth rate } \\
(\%)\end{array}$} \\
\hline 2017.03 & $\$ 2.97$ & $\$ 2.63$ & 0.39 \\
\hline 2016.03 & $\$ 2.14$ & & \multirow{2}{*}{0.12} \\
\cline { 1 - 2 } $2016.07-$ & $\$ 16.02$ & $\$ 5.95$ & \\
\cline { 1 - 2 } 2017.03 & $\$ 14.25$ & & \\
\hline $2015.07-$ & & \\
\hline
\end{tabular}

In addition, according to the latest information from the Pakistan Central Bank, from July to October 2017,Pakistan's foreign direct investment was 940 million US dollars, of which China and Malaysia accounted for the largest share of Pakistan's investment, accounting for $78 \%$ of Pakistan's foreign direct investment. China's direct investment in Pakistan was US\$631.7 million, compared with US\$1.947 in the same period last year, a year-on-year growth rate of 300\%;Malaysia's direct investment in Pakistan was US\$107 million, compared with US\$9.4 million in the same period last year. In terms of industry, the electric energy industry and the construction industry absorbed the most foreign direct investment, which was 422 million US dollars and 177 million US dollars respectively.[5]. (See picture 1)

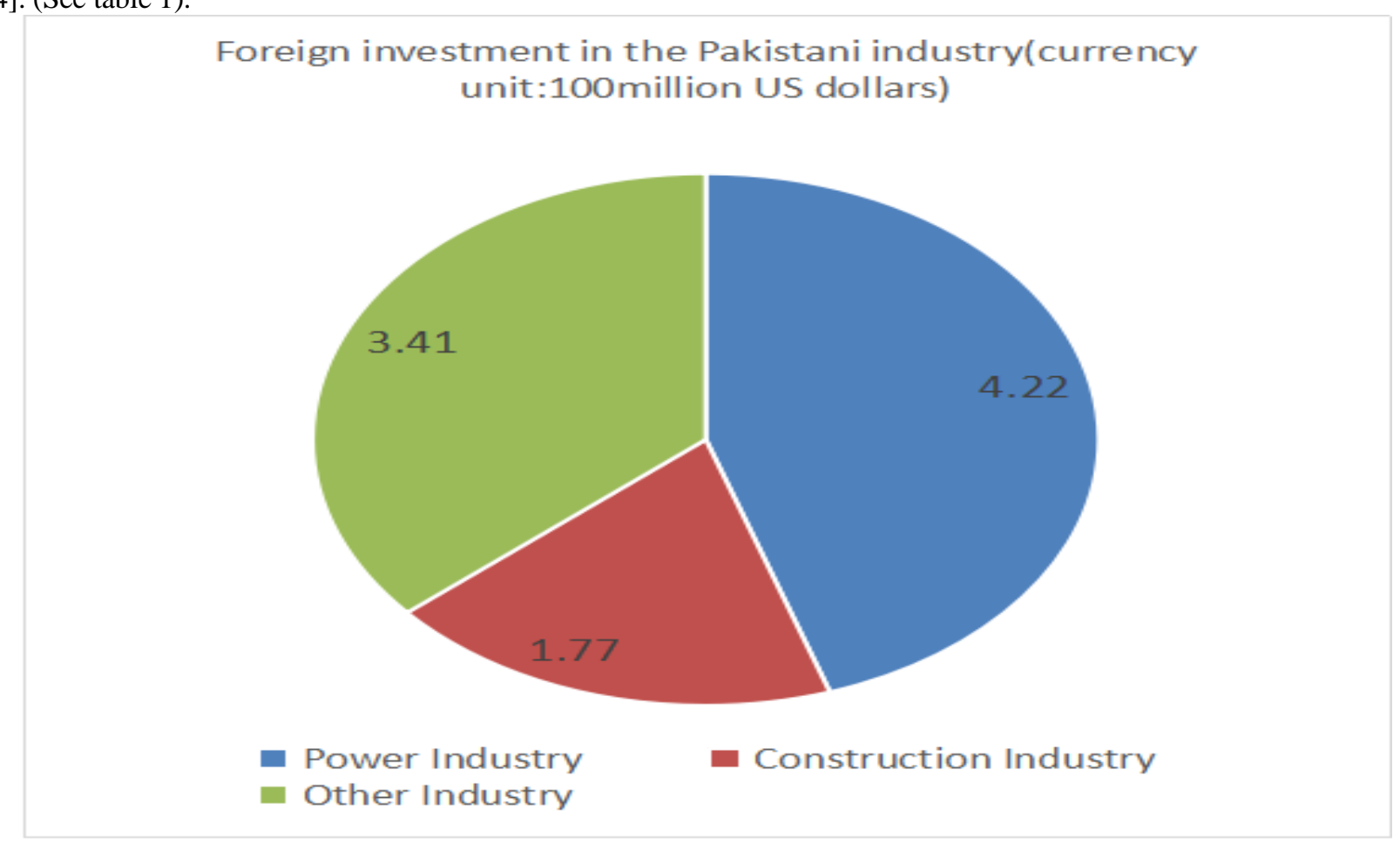

Fig. 1 FOREIGN INVESTMENT IN THE PAKISTANI INDUSTRY(CURRENCY UNIT:100 MILLION US DOLLARS)

After comparing the relevant data and views, it is found that the investment intensity of Chinese enterprises in Pakistan has been heating up recently, and a large amount of capital has flowed into various industries in Pakistan. Compared with investment in other industries, Chinese companies still prefer the energy investment represented by the power industry. As a result, the investment of many Chinese enterprises in energy projects has greatly contributed to Pakistan's economic, living 
0and social development, and also reflects the significance of the "China-Pakistan all-weather strategic partnership."

\section{THE MAIN RISKS FACED BY CHINESE COMPANIES IN ENERGY INVESTMENT IN PAKISTAN}

Earlier, there have been real incident reports of Pakistani terrorists and militants attacking and hijacking Chinese employees. From the news of Xinhuanet on December 8,2017, the terrorist plan recently launched a series of terrorist attacks on Chinese institutions and personnel in Pakistan. The Chinese Embassy in Pakistan reminded Chinese-funded institutions and Chinese citizens in Pakistan to effectively raise their awareness of security, strengthen internal prevention, minimize travel, and avoid going to crowded places. In case of Pakistani police investigation, please cooperate actively.[6]. Obviously, there are a lot of risks in Pakistan. Therefore, it is necessary to discuss the general risks faced by Chinese companies in Pakistan's energy investment as follows.

\section{A. Political risk}

Political risk refers to any type of political event that can cause a profit potential or loss of assets in a transnational business operation. As far as the political risks faced by Chinese companies in investing in energy in Pakistan are concerned, the following points need to be noted.

Firstly, all parties and the military in Pakistan have implemented friendly policies toward China. However, Pakistan's regime has changed frequently and political situation has been chaotic. Specifically in: Pakistan has a political system of one-party rule and multi-party competition. There are about 200 parties in Pakistan, the largest party is the Muslim League (Sharif), and the rest are Muslim Union (Leader) and People's Party. The competition for rights between the federal central government and local governments has divided between the allocation of management resources. The subtle relationship between the Pakistani military and the government. In the history of Pakistan, there have been four military coups. Former Pakistani President Musharraf was a soldier. Later, Musharraf's military and political unity and ruling Pakistan, Pakistan was greatly affected by "authoritarianism".

Secondly, the most important political risk at present is extreme nationalism, religious extremism and terrorism in Pakistan. The three are both differentiated and infiltrated. From the Global Terrorism Index Report 2017,it can be seen that in the countries most affected by terrorist activities in 2016,Pakistan ranked in the top five, one position lower than the previous ranking.[7]. Undoubtedly, the three forces pose a serious threat to Pakistan's domestic security. From the existing data analysis, since 2017, terrorist attacks have taken place in the areas where the China-Pakistan Economic Corridor project, including Gwadar Port, is located. In June 2017,two Chinese were kidnapped and killed in Pakistani terrorist organizations supported by the Islamic State (ISIS) in Quetta, the capital of Balochistan.

Thirdly, be wary of investing in corporate property that is invisibly nationalized. Internationally, due to changes in the political situation of the host country, it is not uncommon for the property of the investing country to be directly confiscated to the host country or to restrict the development of its equity. For example, the 1951 British-Iranian oil company's entire assets were confiscated by the Iranian government; in 2010 the Australian federal government stipulated that companies investing in non-renewable resources should pay $40 \%$ of the profits to the local government. Although the Pakistani government recognizes that all foreign investment can enjoy exclusive $100 \%$ equity, it is estimated that the energy project is expected to increase the cost by 35 billion rupees in May 2017 when the Palestinian side plans to increase the cost of the China-Pakistan Economic Corridor project by 1 percentage point. (about 350 million US dollars), which makes people worry about whether there will be other costs to improve, and ultimately the behavior of the above-mentioned Iraqi and Australian governments invisible nationalized investment countries. According to this, Pakistan's political risks are not small.

\section{B. Economic risks}

The main economic risks of Chinese companies' energy investments in Pakistan are due to Pakistan's weak economy and the exchange rate risk of the US dollar as a measure of investment trade settlement.

To begin with, although Pakistan's economic growth in FY2017 is generally good, its economic weakness has not been fully improved. Political variables (as discussed above).As far as the current foreign dependence of Pakistan's development is concerned, its high dependence on the economies of China, the United States and Saudi Arabia has resulted in more foreign debts and a heavy debt burden. The long-term high inflation rate in Pakistan has led to a decline in GDP. From the perspective of the three industries, the industrial chain is uneven and the development is extremely uneven. Since the founding of Pakistan, the situation of excessive "heavy agriculture and light industry" is still there. The development of the secondary industry is slow, and the tertiary industry has made remarkable progress. However, it is too concentrated in the financial and insurance industry. The trade deficit is high and the current account deficit has soared. Through the economic performance of Pakistan in the fiscal year 2016 2017 quoted by the Ministry of Commerce of the People's Republic of China, it was learned that the export situation of Pakistani goods continued to deteriorate, down $1.63 \%$ year-on-year to US\$20.45 billion, which was lower than US\$21 billion for two consecutive years, a record low in eight years. In contrast, under the influence of the rebound in oil prices in the international market and the growth of capital goods imports driven by CPEC construction, Pakistan's imports increased by $18.7 \%$ year-on-year to US\$53 billion. The trade deficit reached US\$32.58 billion, a year-on-year increase of $36.32 \%$, a record high. The service trade deficit also increased by $5 \%$ year-on-year to US $\$ 3.573$ billion.[8].

What is more, exchange rate risk. As everyone knows, the dollar has the supreme status as a symbol of its "gold standard. "For a long time, Chinese companies have used the US dollar as a medium for foreign investment and settlement. The same is true for Chinese companies investing in Pakistan. Fluctuations in the US dollar exchange rate will have an impact on the costs and benefits of Chinese investment companies. 
The rise or fall of the US dollar or the exchange rate measured by the US dollar is constrained by US domestic savings, US stock market, Fed monetary policy, international gold, oil (energy) and other future economic crises. At a glance, it is difficult to invest in Pakistan.

\section{Legal risks}

The legal risk is interpreted in accordance with the "Administrative Measures for Legal Advisers of State-Owned Enterprises" as: the possibility of negative legal consequences due to changes in the external legal environment of the enterprise or the failure of the enterprise to exercise its rights and perform its obligations in accordance with legal provisions or contractual agreements. When corporate behavior does not comply with legal norms, or lacks awareness of prevention, there will be legal risks.[9]. For example, although Pakistan adopts a comprehensive policy of friendly relations with China, when China and Pakistan sign contracts, they are generally based on the central government or local government. The dispute is not big, but it does not rule out that individual companies that cooperate with China are afterwards. There will be small moves due to vested interests. The main contract is supplemented without the supervision of government personnel, or a new sub-contract is added to achieve the goal. Once Chinese companies lack the sensitivity of such judgments and their unfamiliarity with the legal knowledge of investing in Pakistan, they will fall into legal passiveness and cause losses.

\section{Cross-border cultural risks}

It refers to the uncertainty that affects the transnational investment enterprises by the differences in the religion, language, education, lifestyle, customs and habits of the host country. Although China and Pakistan have traditional deep friendship, the cultural differences between the two countries are quite large. China's cultural traditions are in the Confucian culture, and Pakistan's cultural traditions are derived from Islamic culture. Therefore, there will inevitably be cross-border cultural conflicts between the two countries. The specific two aspects of performance: First, the alienation of cultural values has hindered the cultural formation of China's sub-enterprises in Pakistan's energy investment enterprises. Second, the differences in cultural values have more or less affected the degree of dissatisfaction between the two nationals. When neither side knows the other's culture, the degree of dissatisfaction is even more pronounced.

\section{E. Management system risk}

Management system risk, root chasing refers to the details of the factors that constitute the management system, including the quality of the manager, organizational structure, corporate culture and management process. China's energy-investing enterprises in Pakistan are mostly large and medium-sized state-owned enterprises and have been strictly supervised and assessed by the Chinese government, such as China Power Construction and China Petroleum. Therefore, it is handled well in the three details of the manager's quality, corporate culture and management process, and the problem is not big. On the details of the organizational structure, some Chinese companies have copied their organizational structure in China, and they are dominated by Chinese personnel at the management level of the employers. This is not only bad for the cultivation of management talents in Pakistan, but also has negative effects and is cited. The dissatisfaction of the Pakistani personnel is detrimental to the propaganda of the Chinese company's own image, and even more will be the investment of the profit-and-profit enterprise.

\section{F. Geoenvironment and natural environment risks}

Pakistan in the geo-environment is located in the South Asian subcontinent, in the north is the Taliban's nest in Afghanistan, in the southeast is Pakistan's old rival India, in the west is Iran, where the relationship is not harmonious, the northeast is connected to Xinjiang and Tajikistan, and the Arabian Sea is on the verge. Pakistan's geopolitical conditions are unique, which is reflected in its proximity to the "World Petroleum Center." And a well-connected land is like a doubleedged sword, and it has an unfavorable "geographical risk" side. First, the Afghan Taliban continue to spread terrorist ideas and plan terrorist activities inside Pakistan. Second, Pakistan and India have many years of Kashmir disputes, and the risk of war broke out theoretically. Third, Pakistan and Iran have been struggling in the Balochistan region, relying on Saudi Arabia for funds, and Saudi Arabia is an "old rival" of Iran which makes the relationship between the two countries complicated.

In terms of natural conditions, some of the energy projects invested by Chinese companies are often in complex areas of terrain and climate. For example, there are several projects in the province of Balochistan in southwestern Pakistan. The terrain is undulating, mainly in the mountains, the climate is subtropical, with little rainfall and hot and humid all year round. Such geomorphology and climate increase the difficulty of developing, constructing and constructing energy projects.

\section{G. Game risk}

Refers to the uncertainty of whether each investor can compete for his or her position in a given time and space. The risk of the game is mainly measured from the perspective of the relative returns of each investor. Joseph Greco believes that there is no authority in the international system to organize violence or to violently threaten or enslave other countries, and the core interest of the state is to maintain the status quo of survival, they maintain a high degree of vigilance once In the event of any erosion of their relative ability to survive, they will prevent other countries from gaining a stronger relative ability than their own, that is, relative gains, because they fear that this relative ability will threaten their survival in the future [10]. Today, the countries that invest in Pakistan are not only China, but also the United States, Britain and Japan. Ever since, competition with China has become the norm. Due to the rising pace of China's investment in Pakistan in recent years, the United States, Britain, Japan and other countries have considered that their relative earnings in Pakistan have been threatened by China. Therefore, the United States and Japan have also taken measures to reduce the economic and military forces against Pakistan. Aid and reduce the investment share in Pakistan, Japan and India jointly staged the "Japan-India Economic Corridor", whose overall purpose is to counter 
China's influence in Pakistan and in South Asia. Therefore, the relationship between many countries may be more complicated.

\section{THE PATH AND RECOMMENDATIONS OF RISK MANAGEMENT AND CONTROL}

With the rapid pace of economic globalization, Pakistan is also a jewel in China's "One Belt and Road" strategic position. At present, Chinese energy companies are becoming a hot spot for investment in Pakistan. A good part of the relationship between China and Pakistan is rooted in the long history of China-Pakistan relations. However, as a former "fan" of the United States, whether it will change its normal status to China after a few years, just as China's status today is more important than the United States, these are issues worth considering. A. Berlin said earlier: "In the process of business decisionmaking,risk is always a factor,and the appropriate approach to risk management and mitigation is achieved.This is successful for any new investment or existing business expansion.It is all important."[11]. Therefore, it is imperative to take risks precautions and prescribe the right medicines.

\section{A. Preventing political risks}

Fisrtly, Construct a political risk prevention and control system that "politics by government, political stability by the party, and political promotion by the military."(1).Consolidate the political foundation is to ensure that the most important Chinese enterprises to invest in Pakistan. For instance, realize the interaction between governments at all levels of China and Pakistan, hold multi-level meetings between governments at all levels of China and Pakistan, and form an excellent historical foundation. Regularly hold the China-Pakistan political party exchange meeting, share the experience of the Communist Party of China in the political state with the Pakistani parties, and tend to institutionalize. Increase China-Pakistan cooperation in military affairs, similar to weapons development, military exercises, anti-terrorism and anti-piracy cooperation. (2) China should give security measures on Chinese companies investing in Pakistan, and cultivate a number of security companies that can shoulder heavy responsibilities overseas to consolidate the independence and control of internal security. For example, the security issues on the project can be set up with the means of civil air defense and physical defense controlled by the Chinese side. By deepening the internal security forces in the region where the enterprise is located, it will also be jointly guarded with the Pakistani security forces that are already in the periphery.(3).China should speed up the establishment of the Chinese Enterprise Overseas Investment Insurance Law and innovate the overseas investment insurance system.

Secondly, Chinese enterprises should strengthen their assessment of Pakistan's political risks and their ability to transfer political risks, and establish a platform for assessing investment risks in Pakistan. China's energy-investing companies in Pakistan should assess the political situation in Pakistan from both macro and micro levels. As far as the macro-political level is concerned, because of the high attention of the two governments and the special feelings based on China and Pakistan, the risk assessment is not large. In the micro-political aspect, it is necessary to emphasize the political sensitivity of Chinese enterprises themselves, and to think that actual investment projects and Pakistani politics may affect the macro-political uncertainty to ensure that Chinese enterprises can quickly make unmistakable and accurate judgments in an emergency. Of course, we must also use the strength of various enterprises that have already carried out or are doing business in Pakistan to collect dynamic information on politics, economy, religious culture, terrorist activities, and formulate the "three-dimensional" of Chinese enterprises' investment in Pakistan. The risk assessment plan establishes a platform for the evaluation of China's investment risk database in Pakistan, which is available for reference by various Chinese companies that have invested or invested in Pakistan.

\section{B. Reducing economic risks}

There are two main measures to reduce economic risks.

First, for Pakistan's weak economy, Chinese-funded enterprises should implement diversification of their business strategies and form an operational strategy for the first, second and third full-time industries. They should not be overconcentrated on investments in projects such as energy. According to China advantageous industries such as manufacturing shifted to Pakistan, Pakistan can effectively promote employment and improve the level of Pakistan's national economy, enhance Chinese enterprises in Pakistan's guard force.

Second, vigorously promote the use of the CNY in ChinaPakistan trade and investment settlement, and the Pakistani government needs to be fully and actively guided. The CNY is the fastest currency in the internationalization process and has been included in the special withdrawals by the International Monetary Fund. Therefore, China-Pakistan bilateral trade should be measured in terms of the renminbi to reduce the impact of the dollar and its exchange rate. Of course, this requires the Pakistani government to actively guide.

\section{Circumventing legal risks}

On the one hand, the Chinese project was hired to implement domestic lawyers and Pakistani lawyers to understand the various legal systems in the project location. Lawyers from both China and Pakistan need to have an indepth understanding of the investment market access mechanism (including anti-monopoly review and national security review),the limitation of energy investment projects, taxation of investment income, labor relations, establishment of enterprises and environmental protection.

On the other hand, Chinese-funded enterprises in Pakistan should strengthen their judgment and sharpness in legal literacy, and increase the ability to learn and master relevant legal knowledge of Pakistan through all employees of the company to enhance their ability to resist legal risks. 


\section{Bridging the risk of cross-border culture}

The famous American political scientist Joseph Nye said in his book Soft Power: "The source of soft power comes mainly from the attraction of culture and ideology, and soft power is a cooperative power."[12].Needless to say, the inclusiveness of culture is a fully affirmed aspect of Joseph Nye. Perhaps it is tolerant, you must first be yourself.

First, Chinese-funded enterprises must learn and respect the elements of Pakistani culture such as religion, language, education, lifestyle, customs and habits. At the same time, it is necessary to communicate with local residents and develop a "compassionate" thinking habit and behavior.

Second, China needs to provide security public services in cross-regional economic interactions, create a reputation in China, and enable more countries to trust China. Security public service refers to providing a non-profit service with a peaceful nature, such as peacekeeping, counter-terrorism, antipiracy and other voluntary activities.

Third, Chinese-funded enterprises should shoulder their social responsibilities and vigorously contribute to the local society and seek benefits, thereby enhancing the social influence of enterprises.

\section{E. Resolving the risk of the management system}

Building a scientific and rational management system is critical.

In the first place, both China and Pakistan should pay attention to the appointment of comprehensive talents in understanding the language, law and culture of China and Pakistan.

In the second place, the management level should be equipped with bilateral personnel from China and Pakistan.

\section{$F$. Overcoming the risks of the natural environment by controlling environmental risk and game risk}

In view of the risks arising from the geo-environment and the game, the following steps should be taken to implement the control and provide a good external environment for Chinese enterprises to invest in Pakistan.(1).China must adhere to the concept of "cooperation and win-win" and continuously create inter-regional economic interactions. By forming a cross between the region of South Asia, Central Asia, East Asia, the Middle East as a radiation range of economic interaction Pakistan Economic Corridor by the body, and thus to promote the extension of cooperation between countries and crossregional economic interaction on the body of the strategy "One Belt And Road".(2).China needs to provide security public services in cross-regional economic interactions, create a reputation in China, and enable more countries to trust China. Such as peacekeeping, anti-terrorism, anti-piracy and other voluntary activities. China's military network was quoted from Xinhua News Agency on October 10,2017.Major General Michael Billy, commander of the United Nations Interim Force in Lebanon (UNIFIL), met with visiting Chinese Ambassador to Lebanon Wang Kezhen on the 9th and said that UNIFIL China The peacekeeping team has a superb business and outstanding performance [13].

In the face of the disadvantages of the natural environment should pay attention to two issues.(1).With the leadership of the Chinese government, Chinese-funded enterprises should actively carry out extensive cooperation with the Geography and Meteorological Department of Pakistan and the World Geography and Meteorological Organization, timely implement the early warning mechanism for geographical natural disasters, and arrange the construction progress of the entire project.(2).For Chinese-funded enterprises that suffer losses due to natural disasters, all parties in China and Pakistan should do a good job of condolence work at all levels and provide corresponding subsidies.

\section{CONCLUSION}

Nicholas John Spykman's Marginal Zone Theory has long defined the edge of Eurasia. He believes that Western Europe, the Middle East, South Asia and East Asia are defined as the most important regions of the world. Therefore, Pakistan in the South Asian subcontinent is an important part of China's "One Belt And Road" strategy. Chinese enterprises will continue to invest heavily in it, and it is also crucial to control and prevent risks.

\section{ACKNOWLEDGMENT}

About the author: Di Zhou, from Chongqing Beibei of China, lecturer, Ph.D. in International Relations, Macau University of Science and Technology, research direction: Sino-foreign cultural exchanges.

\section{Contact: Tel 18996233807 Email: 840091439@qq.com}

Mailing address: Room 304, No. 3, 7th Street, Po Shi Street, Xiawan Community, Zhuhai City, Guangdong Province. 


\section{REFERENCES}

[1] Hans Morgans. "Inter-State Politics" [M]. Xu Wei and other translations.Beijing:Chinese People's Public Security University Press, 1990: 160-161. (In Chinese)

[2] Robert Gilpin.War and Change in World Politics [M]. Cambridge: Cambridge University Press, 1981:21-24.

[3] Li Qinqian. Research on China's legal issues of energy investment in ASEAN countries [D]. Nanning: Guangxi Normal University, 2015.(In Chinese)

[4] In the first nine months of 2017, foreign direct investment in Pakistan increased by $12 \%$, and China ranked first. [EB/OL]. http://pk.mofcom.gov.cn/article/jmxw/201704/20170402559637.shtml. (In Chinese)

[5] From July to October 2017, Pakistan's foreign direct investment (FDI) increased by $74.4 \%$ year-on-year, and China firmly took the lead. [EB/OL].http://pk.mofcom.gov.cn/article/jmxw/201711/2017110267122 7. (In Chinese)

[6] Chinese Embassy: Terrorist planning recently launched a terrorist attack on Chinese institutions in Pakistan. [EB/OL]. http://news.xinhuanet.com/world/2017-12/08/c_1122081614.htm. (In Chinese)

[7] Report: China's terrorist impact index fell in 2016. [EB/OL].detailehttp://sputniknews.cn/china/201711151024058824/. (In Chinese)

[8] Pakistan's economic performance in fiscal year 2016-2017 and the economic outlook for the fiscal year 2017-2018. [EB/OL]. http://www.mofcom.gov.cn/article/i/dxfw/cj/201711/20171102667112.s html. (In Chinese)

[9] Beijing Haidian District State-owned Assets Supervision and Administration Commission official website. State-owned enterprise legal advisor management measures [EB/OL]. 2013-11-15. http://gzw.bjhd.gov.cn/zcfg/gjj/201311/t20131115_568592.htm.

[10] Joseph M.Grieco,Anarcy and the Limits of Cooperation :A Realist Critique of the Newest Liberal Institu-tionalism[J]. International Organization, 1988,Vol.42,No3, p.610-612.

[11] A•Berlin,Managing Political Risk in the Oil and Gas Industries[J].Oil Gas and Energy Law,2003,Vol.1,No.2,p.3.

[12] Zhang Xiaoming.Analysis of Joseph Nye's Thought of "Soft Power"[J].American Research, 2005(01):22-24. (In Chinese)

[13] The official military news portal of the Chinese People's Liberation Army. The UNIFIL Commander praised the outstanding performance of the Chinese peacekeeping force [EB/OL].2017-10-10. http://www.81.cn/rd/2017-10/10/content_7781930. (In Chinese) 